\title{
Peran Zakat Produktif dalam Pemberdayaan Ekonomi Mustahiq (Studi Kasus Lembaga Amil Zakat Dompet Dhuafa Republika Yogyakarta 2017)
}

\author{
*Imas Rosi Nugrahani \\ **Richa Angkita Mulyawisdawati \\ * Fakultas Ekonomi Manajemen UNIDA Gontor \\ ** Prodi Perbankan Syari'ah STEBI Al-Muhsin Yogyakarta \\ Email : mulyawisdawati205@gmail.com
}

\begin{abstract}
Indonesia with a majority Muslim population has a large zakat potential. Consumptive zakat distribution will only make mustahiq as recipients. Required distribution of zakat productively to empower mustahiq in order to improve its economy to become muzakki. Productive zakat management carried out by an agency or professional amil zakat institutions, such as the Amil Zakat Dompet Dhuafa Republika Yogyakarta that has been instrumental not only in the country but also abroad. This study aims to determine the role of zakat productive economic empowerment mustahiq in Amil Zakat Dompet Dhuafa Republika Yogyakarta 2017. This research is a descriptive qualitative study using the methods of observation, interview and documentation. Data were analyzed using three inductive data analysis process is the process of data reduction, data presentation and conclusion. The results of this study stated that the role of zakat productive economic empowerment mustahiq in Amil Zakat Dompet Dhuafa Republika Yogyakarta is through the provision of programs of economic empowerment that funds be taken from the fund of productive zakat, the program Kampung Ternak and Institute Mentas Unggul, as well as the provision of socialization, counseling, motivation and ongoing coaching for partners who are being empowered. The program had a positive impact for the economic empowerment mustahiq.
\end{abstract}

Keywords:Zakat Productive, Economic Empowerment, Mustahiq

\begin{abstract}
Abstrak
Indonesia dengan mayoritas penduduk muslim memiliki potensi zakat yang cukup besar. Penyaluran zakat secara konsumtif hanya akan menjadikan mustahiq sebagai penerima zakat. Diperlukan penyaluran zakat secara produktif untuk memberdayakan mustahiq supaya dapat meningkatkan ekonominya hingga menjadi muzakki. Pengelolaan zakat produktif dilakukan oleh badan atau lembaga amil zakat yang profesional, seperti Lembaga Amil Zakat Dompet Dhuafa Republika Yogyakarta yang telah berperan tidak hanya di dalam negeri melainkan juga di luar negeri. Penelitian ini bertujuan untuk mengetahui peran zakat produktif dalam pemberdayaan ekonomi mustahiq di Lembaga Amil Zakat Dompet Dhuafa Republika Yogyakarta. Penelitian ini merupakan penelitian kualitatif deskriptif dengan menggunakan metode observasi,wawancara dan dokumentasi. Teknik analisis data menggunakan tiga proses analisis data induktif yaitu proses reduksi data, kemudian penyajian data dan penarikan kesimpulan. Hasil dari penelitian ini menyatakan bahwa peran zakat produktif dalam pemberdayaan ekonomi mustahiq di Lembaga Amil Zakat Dompet Dhuafa Republika Yogyakarta adalah melalui pengadaan program-program pemberdayaan ekonomi yang dananya diambilkan dari dana zakat produktif, yaitu program Kampung Ternak dan Institut Mentas Unggul, serta dengan pemberian sosialisasi, penyuluhan, motivasi dan pembinaan yang berkesinambungan bagi mitra binaan yang sedang diberdayakan.
\end{abstract}

Kata kunci: Zakat Produktif, Pemberdayaan Ekonomi, Muzakki, Mustahiq 


\section{PENDAHULUAN}

Permasalahan kemiskinan bukan lagi menjadi hal yang baru bagi masyarakat Indonesia. Penyebab kemiskinan sangatlah beragam, diantaranya kualitas sumber daya manusia yang masih rendah, dan pendapatan masyarakat yang tidak merata. Untuk meningkatkan kualitas sumber daya manusia dapat dilakukan dengan cara pemberdayaan masyarakat, khususnya dalam bidang ekonomi untuk meningkatkan kesejahteraan mereka. Pemberdayaan ekonomi masyarakat akan menjadikan masyarakat terberdaya sehingga menggunakan potensi yang dimilikinya untuk bekerja atau berusaha guna meningkatkan kesejahteraan hidupnya. Sedangkan untuk memeratakan pendapatan, dapat digunakan instrumen keuangan berupa zakat. Zakat merupakan salah satu instrumen keuangan negara yang sudah ada sejak zaman Rasulullah SAW dan juga merupakan salah satu dari rukun Islam. Salah satu fungsi dari zakat adalah untuk menciptakan kesejahteraan sosial dengan mewujudkan keadilan yang merata di seluruh kalangan umat atau masyarakat. Zakat diharapkan dapat membantu untuk mengentaskan kemiskinan dan mengurangi kesenjangan pendapatan masyarakat (Mutia et al: 2009). Dalam agama Islam, zakat wajib hukumnya bagi seseorang atau badan yang telah mencapai nisabnya.

Berdasarkan pada data yang penulis dapatkan dari JPNN, Indonesia dengan mayoritas penduduk muslim terbanyak memiliki potensi zakat yang besar. Menurut data Baznas, potensi zakat di Indonesia pada tahun 2017 mencapai Rp 217 triliun, yang mana jika zakat benar-benar dikelola secara maksimal hampir setara dengan $10 \%$ dari APBN. Namun, tidak semua nilai potensi zakat yang cukup besar ini dapat terealisasi seluruhnya. Zakat yang sudah terealisasi di Indonesia hanya sekitar Rp 2,73 triliun atau sekitar $1 \%$ dari potensi zakat yang sebenarnya.

Kewajiban membayar zakat dan penyalurannya yang dilaksanakan secara optimal tidak hanya memberi manfaat keagamaan, melainkan juga dapat memberikan pengaruh yang besar terhadap pemerataan pendapatan bagi seluruh umat Islam (Saini: 2016). Untuk dapat membantu pengoptimalisasian pelaksanaan zakat, telah terdapat badan-badan atau lembaga amil zakat yang memiliki program-program pengumpulan dan penyaluran dana zakat. Zakat dibayarkan oleh seorang muzakki kepada badan-badan tersebut yang bertugas mengumpulkan zakat untuk kemudian didistribusikan kepada mustahiq zakat. Pendistribusian dana zakat dapat dilakukan secara konsumtif atau produktif. Zakat yang disalurkan secara konsumtif akan habis pada jangka waktu yang pendek. Sehingga orang yang diberi zakat atau mustahiq zakat akan terus-menerus menggantungkan dirinya pada dana zakat yang diberikan. Ketergantungan ini tidak akan membawa mustahiq kepada kemandirian, sehingga tidak dapat terwujud kesejahteraan dalam masyarakat. Untuk tujuan tersebut diperlukan penyaluran zakat yang tidak hanya bersifat konsumtif dan tidak hanya membantu mustahiq dalam jangka waktu yang pendek (Halida: 2014). Diperlukan zakat yang bersifat produktif untuk dapat membantu dan memberdayakan para mustahiq supaya mereka dapat meningkatkan kesejahteraan hidupnya untuk jangka waktu yang lebih panjang.

Pada saat ini telah banyak lembaga atau badan amil zakat yang menerapkan program zakat produktif untuk pemberdayaan para mustahiqnya. Lembaga Amil Zakat Dompet Dhuafa Republika merupakan salah satu lembaga amil zakat nasional yang berada di Daerah Istimewa Yogyakarta. Lembaga ini telah menggunakan konsep pemberian zakat dan sedekah untuk program-program pemberdayaan semenjak awal berdirinya pada tahun 1994 dan juga telah berhasil memperluas manfaat zakat. Buktinya adalah bahwa pada tahun 2016 lembaga ini memperoleh salah satu penghargaan utama di Asia karena tidak hanya bekerja untuk Indonesia, tetapi juga untuk Asia Tenggara (Ratna: 2016).

\section{LANDASAN TEORI Zakat Produktif}

Ditinjau dari segi bahasa, kata zakat mempunyai beberapa arti, yaitu al-barakatu (keberkahan), al-namaa (pertumbuhan dan perkembangan), ath-thaharatu (kesucian), dan ash-shalahu (keberesan). Sedangkan secara istilah, zakat adalah bagian dari harta 
dengan persyaratan tertentu, yang diwajibkan oleh Allah SWT kepada pemiliknya, untuk diserahkan kepada yang berhak menerimanya, dengan persyaratan tertentu pula. Zakat mengandung hikmah dan manfaat yang besar dan mulia baik bagi orang yang berzakat (muzakki) ataupun bagi yang menerimanya (mustahiq) (Didin: 2002). Menurut Yusuf Qardhawi pengertian zakat dari segi bahasa adalah keberkahan, pertumbuhan, kesucian, dan kebenaran. Sedangkan zakat dalam istilah adalah sebagian harta yang telah diwajibkan oleh Allah SWT untuk dikeluarkan oleh pemiliknya untuk diberikan kepada para mustahiq zakat (Yusuf: 1973).

Kata produktif secara bahasa berasal dari bahasa Inggris "productive" yang berarti banyak menghasilkan, memberi banyak hasil, mempunyai hasil yang baik. Secara umum produktif berarti banyak menghasilkan karya atau barang (Huda: 2015). Zakat produktif adalah zakat dengan model pendistribusian yang menjadikan para mustahiq dapat menghasilkan sesuatu yang banyak dan secara terus menerus dari harta zakat yang diterimanya. Sehingga harta yang diberikan tidak langsung habis karena dikonsumsi melainkan dikembangkan dengan menggunakannya sebagai modal usaha. Dari usaha tersebut dapat digunakan untuk membantu memenuhi kebutuhan mustahiq secara terus menerus sehingga kelak mustahiq dapat menjadi muzakki (Huda: 2015). Salah satu tujuan zakat diantaranya untuk menghindari penumpukan harta hanya pada sekelompok orang saja. Dengan mendistribusikan zakat secara produktif dapat menjadi alat untuk merealisasikan tujuan tesebut sehingga harta tidak berputar di tangan orang kaya saja (Thoriquddin: 2015). Dalam Al-Qur'an Surat Al-Hasyr Ayat 7 Allah SWT berfirman:

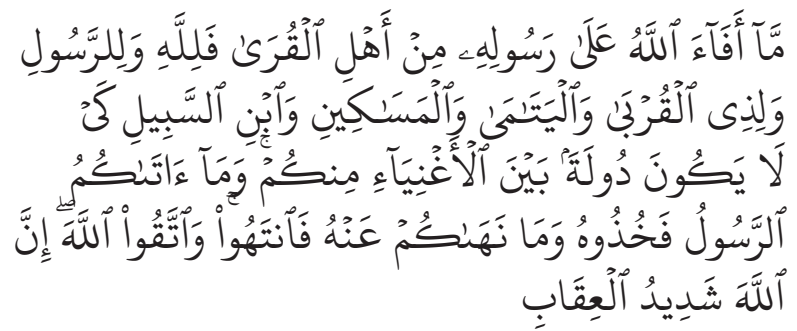

Artinya: "Apa saja harta rampasan (fai) yang diberikan Allah kepada Rasul-Nya (dari harta benda) yang berasal dari penduduk kota-kota maka adalah untuk Allah, untuk rasul, kaum kerabat, anak-anak yatim, orang-orang miskin dan orangorang yang dalam perjalanan, supaya harta itu jangan beredar di antara orang-orang kaya saja di antara kamu. Apa yang diberikan Rasul kepadamu, maka terimalah dan apa yang dilarangnya bagimu, maka tinggalkanlah dan bertakwalah kepada Allah. Sesungguhnya Allah amat keras hukumannya."

Sedangkan dasar hukum zakat produktif terdapat dalam hadist yang diriwayatkan oleh Muslim, yaitu sebagai berikut:

$$
\begin{aligned}
& \text { عن عمر ابن الخطاب رضي الله عنه قال كان رسول الله صلى الله عليه }
\end{aligned}
$$

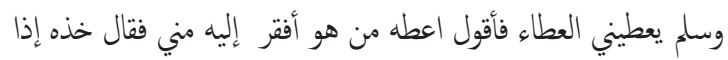

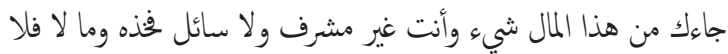

$$
\begin{aligned}
& \text { تتبعه نقسك (رواه مسلم) }
\end{aligned}
$$

Artinya: Dari Umar bin Khattab ra berkata: Rasulullah saw memberikan pemberian kepadaku, lalu saya berkata kepada beliau: Berikanlah kepada orang yang lebih memerlukannya dari pada saya." Beliau bersabda "Ambillah itu (kembangkanlah), apabila ada sesuatu yang datang kepadamu dari harta ini sedangkan kamu tidak melekat (untuk mengambilnya) dan tidak meminta maka ambillah ia. Sesuatu yang tidak (seperti itu) maka janganlah kamu ikutkan dirimu padanya (HR Muslim).

Hadist di atas menunjukkan bahwa harta pemberian yang dapat berupa zakat dapat dikembangkan tidak hanya untuk kebutuhan yang langsung dikonsumsi. Zakat dapat dikembangkan menjadi suatu usaha yang produktif dan menghasilkan keuntungan (Nashrullah: 2015). Harta yang dizakatkan secara produktif merupakan harta yang berkembang. Artinya harta tersebut dapat bertambah karena dijadikan modal untuk usaha yang berpotensi dapat berkembang seperti pertanian, perdagangan, peternakan dan sebagainya. Dalam artian lain, berkembang adalah karena harta tersebut dapat memberikan keuntungan hingga menambah penghasilan atau pendapatan para mustahiq. Sehingga dengan adanya modal usaha diharapkan mustahiq zakat dapat bekerja dan berusaha lebih maksimal untuk memanfaatkan harta zakat produktif yang didapatkannya dengan 
sebaik-baiknya. Dengan demikian mustahiq zakat dapat mencukupi kebutuhannya dan meningkatkan pendapatannya sampai ia memenuhi syarat untuk dapat menjadi muzakki.

Banyak umat Muslim di Indonesia bertanya-tanya mengenai hukum dana zakat yang dijadikan modal usaha oleh mustahiqnya. Untuk menanggapi hal tersebut, Majelis Ulama Indonesia (MUI) mengeluarkan Fatwanya Nomor 4 Tahun 2003 tentang Penggunaan Dana Zakat Untuk Istitsmar (Investasi). Dalam Fatwa MUI tersebut dinyatakan bahwa: "Distribusi zakat mal dari amil kepada mustahiq, yang pada dasarnya harus dilakukan secara langsung, dapat dita'khirkan apabila mustahiqnya belum ada atau ada kemaslahatan yang lebih besar." Selain itu juga terdapat beberapa syarat yang memperbolehkan zakat disalurkan sebagai modal usaha, salah satunya adalah bahwa pengelolaan zakat harus dilakukan oleh institusi atau lembaga yang professional dan dapat dipecaya (amanah).

Di Indonesia terdapat badan atau lembaga tertentu yang sengaja didirikan sebagai pengelola zakat, baik badan atau lembaga milik nasional atau swasta. Diantara badan dan lembaga tersebut adalah Badan Amil Zakat Nasional (BAZNAS) dan Lembaga Amil Zakat (LAZ). Badan Amil Zakat Nasional adalah lembaga yang melakukan pengelolaan zakat secara nasional, sedangkan Lembaga Amil Zakat adalah lembaga yang dibentuk masyarakat yang memiliki tugas membantu pengumpulan, pendistribusian, dan pendayagunaan zakat. Selain BAZNAS dan LAZ, terdapat pula Unit Pengumpulan Zakat (UPZ) yang merupakan satuan organisasi yang dibentuk oleh BAZNAS untuk membantu pengumpulan zakat.

Mustahiq yang menerima zakat produktif berarti ia memiliki kemauan untuk dapat bangkit dan bergerak demi meningkatkan taraf hidupnya hingga kelak ia dapat menjadi muzakki yang telah tercukupi kebutuhannya. Adanya usaha-usaha yang dibangun dari pendayagunaan dana zakat produktif dan menyerap tenaga kerja, maka akan berkontribusi pula dalam pengentasan kemiskinan yang ada di Indonesia serta menciptakan kesejahteraan dan keadilan bagi seluruh rakyat Indonesia (Maulana et al: 2016). Kesejahteraan rakyat dapat dicapai ketika seluruh kebutuhan pokok terpenuhi dan masyarakat dapat terberdaya dengan memiliki penghasilan yang lebih sehingga tidak menggantungkan hidupnya pada dana zakat. Inilah beberapa hikmah yang didapatkan dari pendistribusian zakat secara produktif oleh lembaga atau badan amil zakat yang bertanggung jawab.

\section{Pemberdayaan Ekonomi}

Pemberdayaaan adalah suatu proses yang dilakukan oleh seorang individu atau masyarakat guna meningkatkan kemampuan dirinya supaya dapat berdaya hingga mampu membangun diri dan lingkungan sekitarnya untuk meningkatan kualitas hidup demi mencapai kesejahteraan dan kemandirian (Anwar: 2014). Pemberdayaan juga diartikan sebagai suatu proses yang di dalamnya berisi serangkaian kegiatan untuk tujuan peningkatan kemampuan atau keunggulan bersaing suatu kelompok lemah yang ada dalam masyarakat, termasuk permasalahan mengenai masyarakat miskin. Pemberdayaan berguna untuk meningkatkan nilai utilitas suatu obyek yang diberdayakan melalui kesempatan yang dimilikinya untuk memperbaiki kualitas hidup menjadi yang lebih baik (Totok et al: 2017).

Pemberdayaan disebutkan dalam AlQur'an dengan istilah tamkin (Yulizar et al: 2016). Yang dimaksud dengan tamkin di sini adalah kemampuan melakukan sesuatu, kekokohan, memiliki kekuatan, kekuasaan, pengaruh dan memiliki kedudukan atau tempat, baik yang bersifat materi (hissi) atau yang bersifat non-materi (ma'nawi). Dalam AlQur'an tamkin dibagi menjadi dua bentuk, yaitu tamkin secara maddi (materi) dan tamkin secara ma'nawi (non-materi). Secara maddi berarti manusia telah berdaya atau mampu mengelola bumi dan mencari penghidupan di dalamnya. Dalam Al-Qur'an surat Al-A'raf ayat 10 disebutkan istilah tamkin bersamaan dengan ma'ayish yang berarti sumber kehidupan, Allah SWT berfirman:

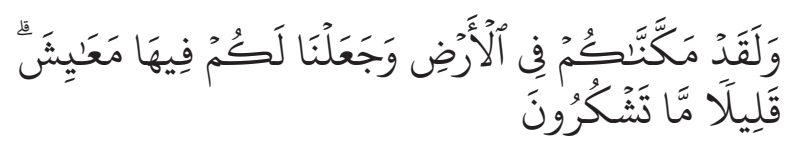

Artinya: "Sesungguhnya Kami telah menempatkan kamu sekalian di muka bumi dan 
Kami adakan bagimu di muka bumi (sumber) penghidupan. Amat sedikitlah kamu bersyukur."

Tamkin secara ma'nawi (non materi), dapat dicapai dengan adanya peneguhan agama dan keamanan manusia. Oleh karena itu manusia harus berusaha menggapai kehidupan yang mulia dengan dua pondasi yang utama, yaitu pondasi agama yang mencakup nilainilai rohani, akhlak dan sosial, dan pondasi keamanan yang menjamin pemenuhan hakhak manusia (Yulizar: 2016).

Pemberdayaan dapat dilakukan kepada individu maupun komunitas atau kelompok. Dalam pemberdayaan individu, proses yang dilakukan adalah dengan peningkatan pengetahuan, motivasi keterampilan, dan pengalaman individu. Dari proses tersebut diharapkan dapat menjadikan individu memiliki daya saing untuk dapat mencapai kemandirian, berperan aktif dalam pembangunan, dan memiliki kemampuan sesuai potensi masingmasing. Pemberdayaan kelompok atau komunitas diartikan sebagai peningkatan kemampuan dari suatu kelompok sehingga dapat mengatur kelompoknya dengan mandiri (Anwar: 2014). Obyek yang diberdayakan adalah individu atau kelompok yang lemah, sehingga dibutuhkan peran orang lain untuk dapat memberdayakannya yang disebut dengan pelaku pemberdayaan. Pelaku pemberdayaan bertugas mendorong, memotivasi dan menciptakan individu atau masyarakat untuk mampu melakukan perubahan menjadi lebih mandiri dan berdaya. Perubahan yang dilakukan mencakup perubahan dari aspek pengetahuan, sikap, maupun keterampilan yang berguna untuk meningkatkan kualitas dan kesejahteraan hidupnya. Pelaku pemberdayaan baik formal maupun informal disebut sebagai agen pemberdayaan.

Tujuan pemberdayaan adalah mengubah perilaku seorang individu atau masyarakat agar mampu berdaya sehingga dapat meningkatan kualitas hidup dan kesejahteraannya. Keberhasilan pemberdayaan dalam prosesnya lebih penting daripada keberhasilan pada hasil akhiryang dicapai. Dalam proses pemberdayaan dibutuhkan partisipasi masyarakat yang aktif sesuai dengan potensi yang dimilikinya dan kebutuhan yang ingin dicukupi. Guna mencapai keberhasilan pemberdayaan, dapat ditempuh dengan strategi pendekatan buttomup yang dilakukan oleh agen pemberdayaan terhadap obyek yang diberdayakan. Dalam strategi ini agen pemberdayaan menggali potensi dan kemampuan yang dimiliki oleh obyek yang diberdayakan untuk kemudian disusun rencana pemberdayaan dan disertai dengan keterlibatan mereka dalam proses pemberdayaan supaya memiliki ikatan emosional demi kesuksesan program.

Pemberdayaan ekonomi lebih banyak dikuatkan dalam bidang pemberdayaan usaha mikro, usaha kecil, dan usaha menengah ke atas, dikarenakan kekuatan ekonomi rakyat terletak padanya. Semakin banyak masyarakat yang terlibat dalam usaha kecil, maka akan tercapailah indikator utama pemberdayaan, yaitu dengan melibatkan atau pastisipasi masyarakat yang sebanyak-banyaknya. Yang diharapkan dari pemberdayaan ekonomi adalah individu atau masyarakat dapat menjadi pelaku usaha kecil yang berkemampuan kompeten dan mandiri, sehingga meningkatkan pendapatan dan kesejahteraan hidupnya (Anwar: 2014).

Ukuran keberhasilan pemberdayaan tidak hanya dilihat dari hasil (output) yang dihasilkan dari proses pemberdayaan. Besarnya partisipasi atau keberdayaan yang dilakukan oleh individu atau masyarakat menjadi tolak ukur yang lebih penting bagi keberhasilan pemberdayaan (Anwar: 2014). Dengan kata lain, pemberdayaan dikatakan berhasil apabila individu atau masyarakat banyak berperan aktif selama melalui proses dan tahapan pemberdayaan sehingga mencapai pada peningkatan kualitas dan kesejahteraan hidupnya.Partisipasi merupakan keterlibatan individu atau masyarakat secara langsung dalam kegiatan pemberdayaan baik fisik maupun psikis. Dengan berpartisipasi, akan memberikan makna dan manfaat yang signfikan terhadap individu sehingga meningkatkan motivasinya untuk mencapai tujuan pemberdayaan. Yang terpenting dalam pemberdayaan adalah mampu menyadarkan masyarakat dan menggerakkannya supaya bersedia melakukan perubahan untuk lebih menggali kemampuan dan potensi dirinya serta meningkatkan kualitas kehidupannya. 
Pemberdayaan biasa dikaitkan dengan pemecahan masalah ekonomi yaitu pengentasan kemiskinan dan kesejahteraan masyarakat. Pengentasan kemiskinan tidak hanya dapat dilihat dari segi peningkatan pendapatan, melainkan aspek-aspek kehidupan dasar lainnya seperti gizi dan kesehatan, ketersediaan lapangan pekerjaan, jumlah keluarga dan anggotanya, tingkat pendidikan, dan lingkungan, serta aspek lainnya yang behubungan dengan kualitas hidup masyarakat yang baik. Pemberdayaan memerlukan proses yang tidak cepat, melainkan harus secara berkesinambungan dengan tahapan-tahapan yang mengubah perilaku individu ke arah yang lebih baik (Anwar: 2014). Yang juga penting dalam kegiatan pemberdayaan adalah pendampingan yang dilakukan oleh agen pemberdayaan terhadap obyek yang diberdayakan. Pendampingan dilakukan karena individu atau kelompok yang diberdayakan adalah lemah. Pendampingan yang dimaksudkan bukanlah yang bertugas menggurui, namun lebih tepatnya adalah sebagai fasilitator, komunikator, dinamisator, dan pembimbing masyarakat di lapangan.

\section{Mustahiq Zakat}

Dalam ayat Al-Qur'an Surat At-Taubah ayat 60 disebutkan mengenai kepada siapa saja zakat harus diberikan atau yang berhak menerima zakat:

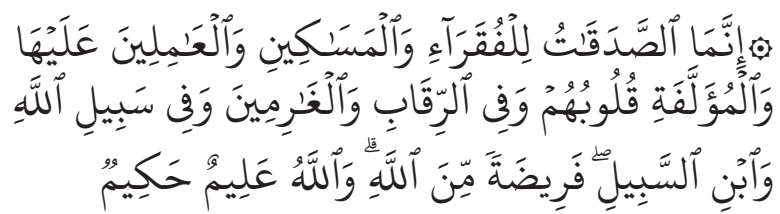

Artinya: "Sesungguhnya zakat-zakat itu, hanyalah untuk orang-orang fakir, orang-orang miskin, pengurus-pengurus zakat, para mu'allaf yang dibujuk hatinya, untuk (memerdekakan) budak, orang-orang yang berhutang, untuk jalan Allah dan untuk mereka yuang sedang dalam perjalanan, sebagai suatu ketetapan yang diwajibkan Allah, dan Allah Maha mengetahui lagi Maha Bijaksana."

Golongan yang menerima zakat seperti yang telah disebutkan dalam ayat di atas dinamakan sebagai asnaf tsamaniyah, dan tidak diperuntukkan kepada selain delapan golongan berikut ini (Maryam: 92):

1. Fakir

Yang tergolong dalam fakir adalah orang yang tidak memiliki pendapatan untuk mencukupi kebutuhan hidupnya. Derajat orang fakir adalah yang paling rendah dari manusia lain di sekitarnya, sehingga menjadi yang paling diutamakan dalam hal pemberian zakat.

2. Miskin

Perbedaan fakir dengan miskin adalah apabila fakir tidak memiliki pendapatan untuk mencukupi kebutuhan hidupnya, sedangkan orang miskin memiliki pendapatan namun tidak dapat mencukupi kebutuhan pokok hidupnya secara menyeluruh, hanya sebagian saja. Dua golongan ini adalah yang menjadi prioritas dalam pemberian zakat.

3. Amil

Amil zakat meliputi orang-orang yang bertugas untuk mengumpulkan harta zakat dari para muzakki, menghitung dan menuliskannya, hingga membagikannya kepada para mustahiq zakat.

4. Muallaf

Yang dimaksudkan dengan muallaf yang berhak menerima zakat adalah orang muslim yang lemah imannya (dengan tujuan supaya menguatkan iman), atau orang kafir yang diharapkan akan masuk Islam.

5. Riqab

Zakat dapat diberikan kepada seorang budak atau hamba sahaya dengan memerdekakannya dari tuannya.

6. Gharim

Mereka adalah orang-orang yang memiliki hutang dan tidak dapat membayarnya. Gharim yang diberi zakat adalah mereka yang mempunyai kebutuhan mendesak supaya hutangnya cepat terlunasi, dan berhutang karena sesuatu hal yang bukan maksiat.

7. Fi Sabilillah

Orang-orang yang sedang berjihad di jalan Allah berhak mendapatkan zakat, baik mereka yang berjihad di medan perang, maupun berjuang menegakkan agama Allah dengan menuntut ilmu, melaksanakan haji, dan sabagainya. 
8. Ibnu Sabil

Para musafir yang sedang dalam perjalanan dan berada dalam kesulitan berhak menerima zakat, meskipun di daerah tempat asalnya ia adalah orang yang kaya.

\section{Lembaga Amil Zakat Dompet Dhuafa Republika Yogyakarta}

Yayasan Dompet Dhuafa Republika diresmikan menjadi Lembaga Zakat Nasional (Lembaga Amil Zakat) oleh Departemen Agama Republik Indonesia pada tanggal 10 Oktober 2001. Lembaga ini pertama kali didirikan oleh empat orang pendiri yang bekerja sebagai jurnalis di koran harian Republika, mereka adalah Parni Hadi, Haidar Bagir, Sinansari Ecip, dan Erie Sudewo pada tanggal 4 September 1994. Sebagai seorang jurnalis, mereka banyak berinteraksi dengan masyarakat miskin dan sering berjumpa dengan orang kaya. Semenjak itulah mucul ide untuk menggalang kebersamaan dengan siapa saja yang memiliki kepedulian terhadap nasib dhuafa.

Dompet Dhuafa Republika merupakan lembaga nirlaba yang didirikan untuk masyarakat Indonesia guna mengangkat harkat sosial kemanusiaan kaum dhuafa melalui dana zakat, infaq, shadaqah, wakaf (ZISWAF) dan lain sebagainya. Dana yang dihimpun adalah dana halal yang dibayarkan oleh perorangan, kelompok, atau perusahaan. Hingga saat ini, lembaga ini semakin menunjukkan keprofesionalitasannya dalam mengadakan program-program kepedulian. Tidak hanya berkhidmat di wilayah negara Indonesia, bahkan telah menjuru ke wilayah internasional di Asia dan sekitarnya.

Berdasarkan Undang-undang RI Nomor 38 Tahun 1999 tentang Pengelolaan Zakat, Dompet Dhuafa merupakan institusi pengelolaan zakat yang dibentuk oleh masyarakat. Pengukuhan Dompet Dhuafa Republika sebagai Lembaga Amil Zakat tingkat Nasional dilakukan oleh Menteri Agama Republik Indonesia dalam Surat Keputusan Nomor 439 Tahun 2001 dan dikeluarkan pada tanggal 8 Oktober 2001.

Dari hasil observasi pada Lembaga Amil Zakat Dompet Dhuafa Republika
Yogyakarta pada hari Jum'at 12 Januari 2018 didapatkan bahwa Mustahiq yang dilayani oleh Dompet Dhuafa disebut dengan penerima manfaat. Sedangkan penerima manfaat yang sedang diberdayakan dan mendapat binaan dari Dompet Dhuafa untuk program pemberdayaan disebut dengan mitra binaan. Hal ini menunjukkan bahwa Dompet Dhuafa menjalin komunikasi yang baik dan sangat menghormati mustahiq yang menjadi sasaran pemberdayaannya. Selain itu, counter yang berada di kantor Dompet Dhuafa Yogyakarta dibedakan antara counter untuk muzakki dan counter untuk mustahiq. Counter bagi muzakki tertelak di bagian depan, dan counter mustahiq terletak di dalam kantor. Pemisahan antara counter muzakki dan mustahiq bertujuan agar mustahiq tidak merasa minder jika datang bersamaan dengan muzakki.

Berdasarkan hasil wawancara penulis dengan Nuryanto Hari Murti, Staf Program Pemberdayaan Ekonomi Dompet Dhuafa Republika Yogyakarta pada hari Jum'at, 12 Januari 2018 diketahui bahwa pemberdayaan yang dilakukan oleh Dompet Dhuafa adalah mencakup empat aspek, yaitu kesehatan, pendidikan, ekonomi, dan pengembangan sosial. Empat aspek tersebutlah yang selalu menjadi penyebab permasalahan kemiskinan di Indonesia. Dalam program kesehatan, Dompet Dhuafa mendirikan berbagai lembaga kesehatan yang bertujuan untuk melayani seluruh mustahiq dengan sistem yang mudah dan terintegrasi dengan sangat baik. Dalam bidang pendidikan, Dompet Dhuafa membantu mewujudkan anak-anak Indonesia dengan masa depan yang lebih baik, melalui pemberian program pendidikan dan beasiswa bagi mereka yang tidak mampu. Pemberdayaan ekonomi dilakukan oleh Dompet Dhuafa kepada seluruh masyarakat yang kurang mampu, demi menciptakan entrepeneur yang baru dan membuka lapangan pekerjaan yang lebih banyak, sehingga dapat memutuskan lingkaran kemiskinan di Indonesia. Untuk membantu saudara-saudara yang sedang tertimpa musibah, Dompet Dhuafa melalui program pengembangan sosial menyalurkan para relawan sebagai wujud kepedulian sosial antar manusia. 


\section{METODE PENELITIAN}

Jenis penelitian ini adalah penelitian lapangan (field research) dengan menggunakan metodekualitatif yang bersifat deskriptif. Adapun objek penelitian kajian ini adalah Lembaga Amil Zakat Dompet Dhuafa Republika Yogyakarta. Teknik pengumpulan data melalui observasi, wawancara kepada pihak yang berkepentingan dalam hal ini Lembaga Amil Zakat Dompet Dhuafa Republika Yogyakarta dan beberapa mustahiq dan dokumentasi. Teknik analisis data menggunakan tiga proses analisis data induktif yaitu proses reduksi data, kemudian penyajian data dan penarikan kesimpulan.

\section{PEMBAHASAN}

\section{Peran Zakat Produktif dalam Pemberdayaan Ekonomi Mustahiq}

Berdasarkan hasil wawancara penulis dengan nara sumber yang sama, sejak awal berdirinya pada tahun 1994, Dompet Dhuafa Republika telah mengutamakan penggunaan dana zakat yang dikumpulkannya sebagai zakat produktif untuk pemberdayaan para mustahiq. Dana zakat yang disalurkan secara produktif berarti bahwa penyaluran dana tidak diberikan kepada mustahiq berupa barang konsumtif seperti uang atau kebutuhan pokok saja, melainkan disalurkan melalui program-program pemberdayaan. Dengan mengikuti program pemberdayaan akan membantu mustahiq supaya bergerak lebih aktif untuk memperbaiki kehidupannya. Mustahiq yang diberdayakan tidak bergantung pada pemberian yang sifatnya konsumtif, yang hanya menjadikannya malas untuk bergerak dan mencari kehidupan. Sebagaimana yang dikemukakan oleh Staf Pemberdayaan Ekonomi Dompet Dhuafa Republika Yogyakarta mengenai definisi pemberdayaan, menurutnya pemberdayaan adalah cara yang ditempuh untuk mengajak para mustahiq berkembang menuju kehidupan yang lebih maju melalui program-program yg diadakan oleh Dompet Dhuafa.

Pemberdayaan dalam bidang ekonomi dilakukan dengan memberikan dorongan kepada mustahiq supaya bersedia untuk mengembangkan kemampuan yang mereka miliki. Kemampuan yang ada kemudian ditambah dengan memberikan keterampilan supaya mereka dapat mengolah sumber daya alam yang ada di sekitarnya. Hasil dari semua itu dapat digunakan untuk menambah penghasilan mereka. Seluruh program pemberdayaan memiliki mekanisme masingmasing yang harus selalu dikembangkan. Amil dari pihak Dompet Dhuafa juga tidak boleh bosan untuk selalu memotivasi mustahiq supaya mereka bergerak maju hingga dapat meningkatkan taraf hidup mereka. Pendekatan yang dilakukan oleh Dompet Dhuafa kepada mustahiq atau penerima manfaatnya adalah dengan pendekatan buttom-up. Yang dimaksud dengan pendekatan buttom-up di sini adalah pihak Dompet Dhuafa dalam memberikan program disesuaikan dengan kemauan dan kemampuan mustahiq, tidak berdasarkan paksaan atau perintah dari pihak Dompet Dhuafa. Kesepakatan mengenai apa yang akan dijadikan bahan usaha selalu disesuaikan oleh kemauan dan kemampuan mustahiq. Selain itu juga disesuaikan dengan apa yang ada dalam suatu desa yang akan diberdayakan masyarakatnya. Sehingga dalam proses pemberdayaan juga dilakukan pengelolaan sumber daya alam. Setelah diberikan modal untuk usaha, mustahiq yang diberdayakan tidak ditinggalkan begitu saja, melainkan selalu didampingi dan mendapat binaan dari pihak Dompet Dhuafa dalam pengelolaan dan penggunaan modal usaha. Contohnya dalam manajemen usaha, mustahiq yang telah memiliki usaha diajarkan untuk memisahkan antara uang modal, hasil usaha, tabungan, dan konsumsi. Jika keuangan usaha dapat tertata dengan rapi, maka akan dapat meningkatkan penghasilan mereka hingga dapat mencapai bahkan melebihi upah minimum regional (UMR).

Pada tahun 2017 Dompet Dhuafa menambah dua program zakat produktif yang berperan dalam pemberdayaan ekonomi mustahiq yaitu program Kampung Ternak dan Institut Mentas Unggul (IMU). Kampung ternak telah diadakan di tiga tempat di kabupaten Bantul, yaitu di Kecamatan Guwosari, Gedong Panjangrejo, dan Lanteng. Sedangkan untuk IMU telah diadakan di dua tempat di kabupaten Gunung Kidul yaitu di kecamatan Patuk dan Nglipar.

Kampung Ternak merupakan suatu program pemberdayaan yang dilaksanakan 
untuk memajukan perekonomian mustahiq melalui beternak. Seorang mustahiq yang belum mempunyai hewan ternak akan diberi hewan ternak untuk dipelihara dan dikembangkan, sedangkan bagi yang sudah memiliki hewan akan diberi pembinaan supaya dapat mengembangkan ternaknya dengan baik. Indikator yang digunakan dalam program pemberdayaan kampung ternak adalah mustahiq dapat mengembangkan aset ternak yang kecil menjadi aset yang besar sehingga dapat digunakan untuk kegiatan berbisnis. Kampung ternak binaan Dompet Dhuafa pertama-tama dilakukan dengan memberikan pembinaan melalui sosialisasi kepada mustahiq mengenai bagaimana cara merawat hewan ternak yang baik, seperti cara melakukan penggemukan serta memberikan kandang yang bersih. Sosialisasi sebelum pelaksanaan sangatlah penting karena akan sangat mempengaruhi pemahaman mustahiq terhadap apa yang akan mereka lakukan. 90\% kegiatan pemberdayaan berhasil disebabkan oleh kekuatan komunikasi yang dilakukan secara rutin melalui sosialisasi.

Selama pemeliharaan hewan ternak oleh mustahiq, staf Dompet Dhuafa selalu melakukan pembinaan, pengontrolan, dan pembenaran apabila mustahiq melakukan kesalahan dalam pemeliharaan. Zakat dengan bentuk penyaluran seperi inilah yang dinamakan dengan zakat produktif yang mana menuntut mustahiq untuk menjadi produktif sehingga penghasilannya bertambah dan sehingga dapat menjadi munfiq sampai muzakki. Dalam distribusi zakat, seluruh dana zakat harus tersalurkan kepada mustahiq, tidak boleh ada sedikitpun yang tersisa bagi lembaga. Penguatan program ini dilakukan dengan meningkatkan kualitas SDM para mustahiq, kemudian untuk mengembangkannya diadakan penyuluhan dari pihak lembaga. Program-program pemberdayaan yang ada dilakukan dengan membentuk kelompokkelompok di suatu desa. Dalam satu kelompok terdiri dari beberapa mustahiq, dan terdapat seorang pendamping dari pihak Dompet Dhuafa yang bertugas mendampingi dan mengontrol jalannya program. Kampung Ternak Kentolan Lor memiliki 24 orang anggota atau mitra binaan yang diberdayakan.
Jangka waktu yang diperlukan untuk dapat memberdayakan mustahiq sehingga dapat meningkatkan penghasilannya adalah minimal satu tahun dan maksimal dua tahun. Untuk program awal biasanya membutuhkan waktu dua tahun, dalam satu tahun pertama mustahiq selalu dikontrol, didampingi, diarahkan, dan diperbaiki supaya tidak terjadi hal-hal yang tidak sesuai dengan tujuan program. Pada satu tahun berikutnya, mustahiq sudah dilepaskan dan sudah mengerti cara yang baik dan benar untuk mengelola peternakan. Pada saat itu sudah tidak lagi ada pendampingan dari pihak Dompet Dhuafa, namun masih tetap membuka pintu bagi mustahiqnya yang hendak berkonsultasi mengenai permasalahan, karena Dompet Dhuafa bersifat konsultatif dalam pemberdayaan mustahiqnya. Setiap program pemberdayaan yang dilakukan dalam suatu kelompok harus dengan akad yang jelas dan disetujui oleh seluruh anggota kelompok.

Pemberdayaan ekonomi mustahiq yang dilakukan oleh Dompet Dhuafa melalui peningkatan keahlian mustahiq, dengan demikian diharapkan dapat mengurangi resiko kematian pada hewan ternak dan meningkatkan pengetahuan mustahiq sehingga menjadi peternak nasional yang lebih baik. Program pemberdayaan mustahiq dengan zakat produktif ini menuntut para mustahiq agar dapat bergerak aktif, masyarakat dirubah secara perlahan, mulai dari paradigma pemikirannya, supaya tidak malas untuk berusaha, kemudian bersedia untuk diberdayakan. Selain pemberdayaan dengan hewan ternak kambing, juga dilakukan pemberdayaan dengan menggunakan hewan ternak sapi. Sapi dapat menjadi suatu aset atau investasi yang besar bagi mustahiq, selain itu juga dapat diambil susunya untuk dijual. Dengan demikian dapat meningkatkan penghasilan mustahiq. Seluruh program yang diadakan di desa-desa, Dompet Dhuafa berkerjasama dengan pihak Dinas Pengawas di tingkat Kecamatan dan di tingkat Desa, supaya ada yang membantu mensukseskan tujuan pemberdayaan mustahiq melalui zakat produktif. Program-program kerja harus sudah direncanakan sebelumnya dan distandarisasi terlebih dahulu supaya dapat dijalankan dengan maksimal.

Selain program Kampung Ternak, program pemberdayaan lainnya adalah Institut Mentas 
Unggul (IMU). Sebuah program pemberdayaan ekonomi yang berusaha meningkatkan keahlian mustahiq dalam suatu keterampilan yang dimilikinya. Dengan indikator pencapaian agar mustahiq dapat menyelesaikan pembelajaran mengenai keterampilannya hingga menjadi ahli dalam bidang tersebut. Dari keterampilan tersebut diharapkan akan dapat mendirikan suatu home industri yang akan menciptakan suatu produk dan membuka lapangan pekerjaan bagi orang banyak.

Pada tahun 2017, Dompet Dhuafa mengadakan program pemberdayaan ekonomi Institut Mentas Unggul (IMU) di dua kecamatan di Kabupaten Gunung Kidul. Dua kecamatan tersebut adalah kecamatan Nglipar dan kecamatan Patuk. Di kecamatan Nglipar, diadakan program budidaya dan home industri aloevera. Aloevera hasil budidaya yang mudah dijumpai di sekitar rumah warga diolah menjadi produk olahan aloevera, yaitu nata de aloevera. Dari nata de aloevera ini diolah kembali menjadi satu cup minuman serat alami yang menyehatkan dan menyegarkan. Yang telah berjalan hingga saat ini adalah produk minuman, namun ke depannya nanti aloevera akan diolah menjadi berbagai macam minuman dan makanan yang lebih bermanfaat dan diminati oleh masyarakat.

Berdasarkan wawancara dengan Ibu Muji Astuti, Mustahiq Zakat Dompet Dhuafa Republika Yogyakarta pada hari Jum'at, 6 April 2018 bahwa Dompet Dhuafa telah berperan banyak dalam proses pemberdayaan ekonomi masyarakat melalui program budidaya dan home industri aloevera ini. Peranannya diwujudkan dalam bentuk pemberian sosialisasi kepada masyarakat mengenai pengolahan aloevera, selain itu pihak Dompet Dhuafa juga giat melakukan pembinaan selama proses pembudidayaan, produksi, dan pemasaran aloevera. Peranan yang sangat dapat dilihat adalah Dompet Dhuafa memberikan peralatan yang berguna untuk budidaya aloevera, seperti bibit, polybag, pupuk, selang dan alat penyiram tanaman. Apabila aloevera milik warga telah dapat dipanen, Dompet Dhuafa akan mengajarkan ibu-ibu anggota kelompok supaya dapat mengolah aloevera menjadi produk lain yang dapat dijual juga selain sebagai minuman.
Program Institut Mentas Unggul kedua yang dikunjungi peneliti adalah home industri keripik pisang "Cripang" yang diadakan oleh Dompet Dhuafa untuk memberdayakan ibu-ibu Desa Semoyo Kecamatan Patuk Kabupaten Gunung Kidul. Motivasi ibu-ibu untuk mengikuti program ini yang paling utama adalah untuk meningkatkan ekonomi keluarga, selain itu juga untuk memajukan jamaah pengajian yang ada di masjid, karena anggota home industri merupakan ibu-ibu jamaah masjid, supaya meningkatkan infaq masjid dan memperbanyak jamaahnya.

Dalam home industri ini, Dompet Dhuafa berperan dalam pemberian modal awal untuk produksi kripik pisang dengan besar modal sejumlah Rp 11.000.000,- untuk produksi dan Rp 6.000.000,- untuk pemasaran. Selain modal dalam bentuk uang, juga diberikan peralatanperalatan yang dibutuhkan untuk proses produksi keripik pisang. Peran selanjutnya yaitu pemberian sosialisasi mengenai pembuatan kripik pisang yang beraneka rasa dengan tujuan supaya menjadi konsumsi kaum menengah ke atas. Pembinaan dalam proses produksi hingga pemasaran juga dilakukan oleh Dompet Dhuafa, serta pemberian motivasi supaya mitra binaan dapat maju bersama dan tidak hanya memikirkan kepentingan pribadi.

Dari kedua program pemberdayaan di atas, dapat kita ketahui bahwa dana zakat produktif yang berhasil dikumpulkan oleh Dompet Dhuafa Republika cabang Yogyakarta, berperan dalam pemberdayaan ekonomi mustahiq melalui program-program yang sebelumnya telah terencana dan terpikirkan dengan baik. Dana zakat produktif tidak dapat berperan dalam pemberdayaan ekonomi mustahiq jika hanya dengan cara pemberian dana saja, melainkan dibutuhkan beberapa usaha yang lebih, seperti pengadaan sosialisasi atau pengarahan mengenai kepentingan program yang akan dilaksanakan, pembinaan dan pendampingan selama pelaksanaan program, dan pemberian motivasi supaya mustahiq selalu aktif dan tidak mudah putus asa dalam usahanya untuk menjadi yang lebih baik dalam segala hal.

Segala macam usaha yang telah dilakukan untuk pemberdayaan mustahiq tidak akan berhasil apabila dalam diri seorang 
mustahiq tidak ada kemauan untuk maju dan menjadi yang lebih baik. Oleh karena itu, sebagai agen pemberdaya, harus dapat menyadarkan obyek yang diberdayakan bahwasanya kesuksesan tidak akan dapat diraih tanpa adanya usaha yang keras dan selalu mendekatkan diri kepada Sang Maha Kaya, Allah SWT. Selain diberdayakan dari segi material, pemberdayaan yang lebih utama adalah dari segi rohani. Dompet Dhuafa Republika senantiasa mewajibkan mitra binaannya yang telah berhasil supaya tidak lupa untuk menginfakkan hasil yang telah didapatkannya. Karena sesungguhnya tujuan utama dari pemberdayaan mustahiq adalah supaya dapat berubah menjadi muzakki. Dengan meningkatnya jumlah muzakki, maka kesejahteraan dapat terwujudkan.

\section{KESIMPULAN}

Peran zakat produktif dalam pemberdayaan ekonomi mustahiq di Lembaga Amil Zakat Dompet Dhuafa Republika Yogyakarta adalah melalui pengadaan programprogram pemberdayaan ekonomi yang dananya diambilkan dari dana zakat produktif. Terdapat dua program pemberdayaan ekonomi yang dikelola oleh Dompet Dhuafa Republika Yogyakarta, yaitu Kampung Ternak dan Institut Mentas Unggul. Program Kampung Ternak merupakan program pemberdayaan ekonomi yang mengajak mustahiq untuk berdaya melalui ternak hewan kambing atau sapi. Sedangkan Institut Mentas Unggul adalah program pemberdayaan ekonomi melalui budidaya dan home industri tanaman aloevera serta home industri keripik pisang. Peran yang diberikan oleh zakat produktif Dompet Dhuafa dalam pemberdayaan ekonomi mustahiq tidak hanya dengan pemberian modal, baik dalam bentuk uang atau barang. Peran yang diberikan juga berbentuk pemberian sosialisasi, penyuluhan, motivasi dan pembinaan yang berkesinambungan bagi mitra binaan yang sedang diberdayakan

\section{DAFTAR PUSTAKA}

Al-Qur'anul Karim.

Ad-Dugustani, Maryam Ahmad, 1992, Masharif az-Zakah Fii as-Syari'ah al-Islamiyah, AlQohiroh: Matba'ah Islamiyah Haditsah.
Al-Qardhawi, Yusuf, 1973, Figh Zakat Dirasah Muqaranah Liahkamiha Wafalsafatuha Fi Dhauil Qur'an Wasunnah, Cetakan Kedua, Beirut: Muassasaturrisalah.

Anwar, Oos M, 2014, Pemberdayaan Masyarakat di Era Global,Bandung: Alfabeta.

Dompet Dhuafa, Profil, http:/ / dompetdhuafa. org/, (10 Maret 2018 pukul 17.20 WIB).

Dompet Dhuafa, Tentang Kami, http:/ /jogja. dompetdhuafa.org/tentang-kami/visimisi/, (10 Maret 2018 pukul 17.20 WIB).

Fatwa Majelis Ulama Indonesia Nomor 4 Tahun 2003 tentang Penggunaan Dana Zakat Untuk Istitsmar (Investasi).

Hafidhuddin, Didin, 2002, Zakat dalam Perekonomian Modern, Jakarta: Gema Insani.

Halida, Siti, 2014, Pengaruh Pendayagunaan Zakat Produktif terhadap Pemberdayaan Mustahiq di Kota Medan, Jurnal Ekonomi dan Keuangan, Vol. 2, No. 6.

Huda, Nurul, dkk, 2015, Zakat PerspektifMikroMakro, Jakarta: Prenadamedia Group.

JPNN, Potensi Zakat di Indonesia Bisa Capai Rp 217 triliun, http:// www.jpnn.com/ news/ potensi-zakat-di-indonesia-bisacapai-rp-217-triliun, (08 Januari 2018 pukul 22.46 WIB).

Mardikanto, Totok, dkk, 2017, Pemberdayaan Masyarakat dalam Perspektif Kebijakan Publik, Bandung: Alfabeta.

Maulana, Muhammad Rizky, dkk, 2016, Optimalisasi Pendayagunaan Dana Zakat Produktif dalam Pemberdayaan Mustahiq Zakat di PKPU Kota Bandung, Jurnal Keuangan dan Perbankan Syariah, Vol. 2, No. 1.

Menteri Hukum dan Hak Asasi Manusia Republik Indonesia, 2011, Undangundang Republik Indonesia Nomor 23 Tahun 2011 tentang Pengelolaan Zakat, Jakarta: November.

Mutia, Agustina dan Anzu Elvia Zahara, 2009,Analisis Faktor-Faktor yang Mempengaruhi Kesejahteraan Ekonomi Mustahik Melalui Pemberdayaan Zakat (Studi Kasus Penyaluran Zakat Produkif/ Modal Usaha pada Bazda Kota Jambi), Jurnal Konsektualita, Vol. 25, No. 1.

Nasrullah, 2015, Regulasi Zakat dan Penerapan Zakat Produktif sebagai Penunjang 
Pemberdayaan Masyarakat (Studi Kasus pada Baitul Mal Kabupaten Aceh Utara), Jurnal Inverensi, Vol. 9, No. 1.

Observasi Lembaga Amil Zakat Dompet Dhuafa Republika Yogyakarta (Jum'at 12 Januari 2018).

Ratna Ajeng Tejomukti, Dompet Dhuafa Raih Ramon Magsaysay Award, http:// dompetdhuafa.org/read/20160728/ dompet.dhuafa.raih .ramon .magsaysay .award. 2016, (08 Januari 2018 pukul 22.46 WIB).

Saini, Mukhamat, 2016, Pemberdayaan Ekonomi Umat Melalui Zakat Produktif (Studi Kasus Atas Tata Kelola Badan Amil Zakat Nasional [BAZNAS] Kabupaten Nganjuk), Jurnal Lentera, Vol. 14, No. 2.
Sanrego, Yulizar D, dkk, 2016, Fiqih Tamkin (Fiqih Pemberdayaan) Membangun Modal Sosial Dalam Mewujudkan Khoiru Ummah, Jakarta: Qisthi Press.

Syaikh, Muhammad bin Ibrahim bin Abdul Latif Ali, 1419, Syarkh Kitab Adab al-Masyi Ilaa as-Sholat Wal'ibadat, Juz 1, Riyad: Mamlakah Arabiyah Suudiyah.

Thoriquddin, Moh, 2015, Pengelolaan Zakat Produktif Perspektif Maqashid Al-Syari'ah Ibnu Asyur, Malang: UIN Maliki Press.

Wawancara dengan Ibu Muji Astuti, Mustahiq Zakat Dompet Dhuafa Republika Yogyakarta (Jum'at, 6 April 2018).

Wawancara dengan Nuryanto Hari Murti, Staf Program Pemberdayaan Ekonomi Dompet Dhuafa Republika Yogyakarta (Jum'at 12 Januari 2018). 